\title{
Lessons from the 2018 International Symposium on Alternatives Assessment: Advances and reflections on practice and ongoing needs to build the field
}

Tickner, Joel; Simon, Rachel; Jacobs, Molly ; Rudisill, Cathy; Tanir, Jennifer; Heine, Lauren; Spencer, Pamela; Fantke, Peter; Malloy, Timothy F.; Edwards, Sally

Total number of authors:

11

Published in:

Environmental Toxicology and Chemistry

Link to article, DOI:

$10.1002 /$ ieam.4213

Publication date:

2019

Document Version

Peer reviewed version

Link back to DTU Orbit

Citation (APA):

Tickner, J., Simon, R., Jacobs, M., Rudisill, C., Tanir, J., Heine, L., Spencer, P., Fantke, P., Malloy, T. F., Edwards, S., \& Zhou, X. (2019). Lessons from the 2018 International Symposium on Alternatives Assessment: Advances and reflections on practice and ongoing needs to build the field. Environmental Toxicology and Chemistry, 15(6), 909-916. https://doi.org/10.1002/ieam.4213

\section{General rights}

Copyright and moral rights for the publications made accessible in the public portal are retained by the authors and/or other copyright owners and it is a condition of accessing publications that users recognise and abide by the legal requirements associated with these rights.

- Users may download and print one copy of any publication from the public portal for the purpose of private study or research.

- You may not further distribute the material or use it for any profit-making activity or commercial gain

- You may freely distribute the URL identifying the publication in the public portal 


\section{Lessons from the 2018 International Symposium on Alternatives Assessment: Advances and Reflections on Practice and Ongoing Needs to Build the Field}

\section{RUNNING HEAD: 2018 Symposium on Alternatives Assessment Highlights}

\section{AUTHORS}

\begin{tabular}{|c|c|c|c|}
\hline Name & Affiliation & E-mail & $\begin{array}{l}\text { Institutional } \\
\text { address }\end{array}$ \\
\hline $\begin{array}{l}\text { Joel } \\
\text { Tickner }\end{array}$ & $\begin{array}{l}\text { University of Massachusetts } \\
\text { Lowell, Department of Public } \\
\text { Health, Lowell, Massachusetts, } \\
\text { USA } \\
\text { Lowell Center for Sustainable } \\
\text { Production, University of } \\
\text { Massachusetts Lowell, Lowell, } \\
\text { Massachusetts, USA }\end{array}$ & joel_tickner@uml.edu & $\begin{array}{l}600 \text { Suffolk } \\
\text { Street, Lowell, } \\
\text { MA } 01854\end{array}$ \\
\hline $\begin{array}{l}\text { Rachel } \\
\text { Simon* }\end{array}$ & $\begin{array}{l}\text { University of Massachusetts } \\
\text { Lowell, Department of Public } \\
\text { Health, Lowell, Massachusetts, } \\
\text { USA } \\
\text { Lowell Center for Sustainable } \\
\text { Production, University of } \\
\text { Massachusetts Lowell, Lowell, } \\
\text { Massachusetts, USA }\end{array}$ & rachel_simon@uml.edu & $\begin{array}{l}600 \text { Suffolk } \\
\text { Street, Lowell, } \\
\text { MA } 01854\end{array}$ \\
\hline $\begin{array}{l}\text { Molly } \\
\text { Jacobs }\end{array}$ & $\begin{array}{l}\text { University of Massachusetts } \\
\text { Lowell, Department of Public } \\
\text { Health, Lowell, Massachusetts, } \\
\text { USA } \\
\text { Lowell Center for Sustainable } \\
\text { Production, University of } \\
\text { Massachusetts Lowell, Lowell, } \\
\text { Massachusetts, USA }\end{array}$ & mjacobs@envhealth.net & $\begin{array}{l}600 \text { Suffolk } \\
\text { Street, Lowell, } \\
\text { MA } 01854\end{array}$ \\
\hline Cathy & SRC, Inc. & Rudisill@srcinc.com & $\begin{array}{l}7502 \text { Round } \\
\text { Pond Rd, }\end{array}$ \\
\hline
\end{tabular}

This article has been accepted for publication and undergone full peer review but has not been through the copyediting, typesetting, pagination and proofreading process, which may lead to differences between this version and the Version of Record. Please cite this article as doi: 10.1002/ieam.4213.

This article is protected by copyright. All rights reserved. 


\begin{tabular}{|c|c|c|c|}
\hline Rudisill & & & $\begin{array}{l}\text { Syracuse, NY } \\
13212\end{array}$ \\
\hline $\begin{array}{l}\text { Jennifer } \\
\text { Tanir }\end{array}$ & ToxServices LLC & jtanir@toxservices.com & $\begin{array}{l}1367 \\
\text { Connecticut } \\
\text { Avenue NW, } \\
\text { Suite } 300 \\
\text { Washington, } \\
\text { DC } 20036\end{array}$ \\
\hline $\begin{array}{l}\text { Lauren } \\
\text { Heine }\end{array}$ & Northwest Green Chemistry & lheine@northwestgreenchemistry.org & $\begin{array}{l}101 \text { Yesler Way } \\
\text { Ste } 600 \\
\text { Seattle WA } \\
98104\end{array}$ \\
\hline $\begin{array}{l}\text { Pamela } \\
\text { Spencer }\end{array}$ & ANGUS Chemical Company & pjspencer@angus.com & $\begin{array}{l}1500 \text { E. Lake } \\
\text { Cook Rd } \\
\text { Buffalo Grove, } \\
\text { IL } \\
60089\end{array}$ \\
\hline $\begin{array}{l}\text { Peter } \\
\text { Fantke }\end{array}$ & $\begin{array}{l}\text { Technical University of } \\
\text { Denmark, Quantitative } \\
\text { Sustainability Assessment } \\
\text { Group }\end{array}$ & pefan@dtu.dk & $\begin{array}{l}\text { Diplomvej 371, } \\
2800 \text { Kgs. } \\
\text { Lyngby, } \\
\text { Denmark }\end{array}$ \\
\hline $\begin{array}{l}\text { Tim } \\
\text { Malloy }\end{array}$ & $\begin{array}{l}\text { University of California Los } \\
\text { Angeles, Sustainable } \\
\text { Technology Policy Program, } \\
\text { School of Law \& School of } \\
\text { Public Health }\end{array}$ & malloy@law.ucla.edu & $\begin{array}{l}405 \text { Hilgard } \\
\text { Avenue } \\
\text { Los Angeles, } \\
\text { CA } 90095\end{array}$ \\
\hline $\begin{array}{l}\text { Sally } \\
\text { Edwards }\end{array}$ & $\begin{array}{l}\text { Lowell Center for Sustainable } \\
\text { Production, University of } \\
\text { Massachusetts Lowell, Lowell, } \\
\text { Massachusetts, USA }\end{array}$ & sally_edwards@uml.edu & $\begin{array}{l}600 \text { Suffolk } \\
\text { Street, Lowell, } \\
\text { MA } 01854\end{array}$ \\
\hline $\begin{array}{l}\text { Xiaoying } \\
\text { Zhou }\end{array}$ & $\begin{array}{l}\text { Safer Consumer Products } \\
\text { Program, California } \\
\text { Department of Toxic } \\
\text { Substances Control }\end{array}$ & Xiaoying.Zhou@dtsc.ca.gov & $\begin{array}{l}1001 \text { I Street, } \\
\text { Sacramento, CA }\end{array}$ \\
\hline
\end{tabular}

This article is protected by copyright. All rights reserved. 


\section{ACKNOWLEDGMENT}

The authors are grateful for the time and expertise of alternatives assessment content experts who contributed to the development of the Symposium agenda and the formation of the Association for the Advancement of Alternatives Assessment: Jessica Schifano, Karl Palmer, and Meredith Williams. This Symposium was supported in part by major conference sponsorship from the California Department of Toxic Substances Control (DTSC) Safer Consumer Products (SCP) program and National Institute of Environmental Health Sciences (NIEHS). Additional sponsors include: The Oregon Department of Environmental Quality, Washington State Department of Ecology, ToxServices LLC, Verisk 3E, Scivera, the American Chemistry Council (ACC), and the Household and Commercial Products Association (HCPA).

\section{DISCLAIMER}

The authors declare no conflicts of interest.

\section{DATA ACCESSIBILITY}

No data, associated metadata, or calculation tools were used in the preparation of this manuscript.

\section{ABSTRACT:}

Alternatives Assessment is gaining traction as a systematic method to support the informed substitution of chemicals of concern. The 2018 International Symposium on Alternatives Assessment, on November 1-2, 2018 convened nearly 150 professionals from government agencies, industry, consultant firms, academia and advocacy

This article is protected by copyright. All rights reserved. 
organizations to advance a greater understanding of the evolving methods, practices and challenges in the use of alternatives assessment. This article reviews highlights and lessons from the Symposium, including: (1) notable advances in methods, (2) shared insights from practitioners on best practices as well as inherent tensions and challenges, and (3) research and practice needs in the field that can be addressed by organizations such as the newly launched Association for the Advancement of Alternatives Assessment. Being interdisciplinary in nature, the establishment of educational frameworks across disciplines and inclusion of diverse expertise in hazard and exposure assessments, life cycle impacts considerations, design principles, and economic and engineering evaluations will ensure continued growth of the field.

\section{KEYWORDS:}

- Alternatives analysis

- Toxic chemicals

- Hazard assessment

- Decision analysis

- Informed substitution

\section{BACKGROUND AND CONTEXT}

For nearly two decades, alternatives assessment has evolved as a systematic approach to identify, evaluate and adopt safer and feasible substitutes to hazardous chemicals of concern (Jacobs et al. 2016; NRC 2014). Alternatives assessment supports informed substitution, defined as "the considered transition from a chemical of particular concern to safer chemicals or non-chemical alternatives” (U.S. EPA 2009) by utilizing best available information. Both regulatory and market drivers for

This article is protected by copyright. All rights reserved. 
safer, more sustainable chemicals and products have fueled a significant growth in methods, tools, and guidance to support alternatives assessment. For instance, the European Union's Registration, Evaluation, and Authorization of Chemicals (REACH) regulation (EU 2006) requires analyses of alternatives by companies seeking authorization to continue use of a Substance of Very High Concern (SVHC). More recently, several U.S. states have issued regulatory requirements incorporating alternatives assessment as part of restriction of specific chemicals of concern. These include California's Safer Consumer Products (SCP) regulations (CA Code of Regulations 2013), Oregon’s 2015 Toxic Free Kid’s Act (Oregon Health Authority 2018) and Washington's 2018 potential ban on per- and poly fluoroalkyl substances (PFAS) in food packaging (WA RCW 2018). In 2018, major retailers such as Home Depot, Lowes and Amazon restricted the sale of methylene chloride- and Nmethylpyrrolidone-based paint strippers (Chemical Watch 2018a; Sciacca 2018) guided, in part, by the demonstration of available safer alternatives (Jacobs et al. 2015; Morose et al. 2017).

While these drivers have accelerated recent developments in alternatives assessment, the field has suffered from a lack of formal organization and leadership. To significantly grow the field, as well as highlight advances in alternatives assessment methods and practice, the National Institute for Environmental Health Sciences and California Department of Toxic Substances Control, among others, sponsored the 2018 International Symposium on Alternatives Assessment on November 1-2, in Sacramento, CA. Nearly 150 professionals from government agencies, industry, consultant firms, academia, and advocacy organizations attended. Participants were largely from the United States, although individuals from the European Union and Canada were also in attendance.

This article is protected by copyright. All rights reserved. 
Through plenary and parallel scientific sessions, the Symposium advanced a greater understanding among participants of the evolving methods, practices, applications, and challenges concerning the use of alternatives assessment to support informed substitution. As described by keynote speaker, Mary O’Brien (whose book Making Better Environmental Decisions: An Alternative to Risk Assessment (2000) launched the present-day AA movement), alternatives assessment can drive a mindset change in how we think about chemicals assessment and management, one that moves us away from principally accepting and managing the risks of toxic chemicals to exploring whether there are safer, viable options. Alternatives assessment is different than other chemical assessment techniques as a result of: (a) the questions it seeks to answer, is there a safer and feasible alternative, (b) its intrinsic connection to policy and business decision making, and (c) its multidisciplinary approach. The Symposium made clear that alternatives assessment has emerged as a distinct field with its own community of practitioners, affirming the need for a stand-alone professional society, the Association for the Advancement of Alternatives Assessment (A4), which was officially launched during the meeting.

This article reviews highlights and lessons from the Symposium, including: (1) notable advances in methods, (2) shared insights from practitioners on best practices, inherent tensions and challenges, and (3) specific research and practice needs in the field that can be addressed by organizations such as the newly launched A4.

\section{ADVANCING THE SCIENCE OF ALTERNATIVES ASSESSMENT}

The Symposium began with a historical overview of the field of alternatives assessment (Table 1 lists the key elements of an alternatives assessment). Based on This article is protected by copyright. All rights reserved. 
conceptual inspirations stemming from as early as 1969 in the National Environmental Policy Act, alternatives assessment emerged in the 1990s as a distinct science-policy field to guide the informed substitution of hazardous chemicals (NRC 2014). The National Research Council (NRC 2014) defines alternatives assessment as “a process for identifying, comparing, and selecting safer alternatives to chemicals of concern on the basis of their hazards, comparative exposure, performance, and economic viability.” The NRC framework marked an important evolution in alternatives assessment, building on earlier advances in the field by: (1) incorporating elements that have consistently been included among many of the existing frameworks, (2) addressing aspects that have been largely lacking in many of the previous methodologies, and (3) generally adding to the legitimacy of the approach as distinct from a risk assessment or sustainability assessment (NRC 2014). Some of the historical milestones in the evolution of alternatives assessment and informed substitution are outlined in Figure 1 (based on Tickner, 2018). Following the NRC report, and the subsequent 2015 International Symposium on Alternatives Assessment — which identified research and practice gaps for the field — there have been a number of important developments in data sources, tools, methods, and guidance.

\section{Developments in hazard assessment}

With much of the focus of alternatives assessment on the hazard assessment elements of evaluations, several presenters focused on their research and recent experiences filling toxicity data gaps using predictive toxicology data and associated tools - a key methodological issue identified by Tickner et al. (this issue) and Malloy, Zaunbrecher, Beryt, et al. (2017). For example, the Health and Environmental 
Sciences Institute's (HESI's) Sustainable Chemical Alternatives Committee developed comprehensive guidance for filling hazard data gaps using predictive toxicology data and tools, and a weight-of-evidence approach (Spencer, 2018). The guidance outlines a tiered stage gate process for the use of available data sources such as cheminformatics and in-silico models, when there is not adequate information for endpoint hazard assessment. This includes read-across structural activity relationships and quantitative structure-activity relationships (QSARs), and generating additional data (e.g. in-chemico, in-vitro, in-vivo, ex-vivo). Numerous case examples exist where predictive toxicology tools have been applied to fill data gaps for a range of hazard endpoints in hazard assessment processes, building experience in practice (NRC 2014; Smith 2018; Kim et al. 2018).

Presenters also highlighted the need to complement qualitative hazard assessment methods with additional scoring approaches. Current scoring methods frequently sort alternatives into specific categories, such as "High hazard" "Moderate Hazard”, “Low Hazard” (CPA 2017; EPA 2011). In some assessments, many alternatives are placed into the same category and are thus difficult to differentiate. Several new approaches were presented, including methods developed by Scivera, Levi Strauss \& Co, and Nike that calculate a numerical score for a chemical alternative based on hazard assessment results (Rinkevich et al. 2018). Both Nike and Levi Strauss \& Co have also created methods for hazard scoring at both the ingredient- and formulation-level and are working with other brands through the Zero Discharge of Hazardous Chemicals (ZDHC) organization to create an aligned “Screened Chemistry” approach for the apparel sector (Rinkevich et al. 2018). Both Nike and Levi Strauss \& Co. stressed the importance of moving towards a formulation-level hazard assessment approach that supports the ability of This article is protected by copyright. All rights reserved. 
manufacturers to identify specific chemical ingredient impacts within a formulation and adjust as needed to improve the overall formulation score, thus driving innovation not just at the ingredient-level, but at the formulation-level as well.

\section{Developments in comparative exposure assessment}

Presenters discussed the continued need to incorporate comparative exposure considerations in alternatives assessment, as described in the NRC report (2014). The report highlighted the importance of considering the intrinsic potential for comparative exposure trade-offs without physical or administrative controls (NRC 2014). Prior to the NRC report, exposure information was only minimally considered in most alternatives assessments since the main focus has been to identify alternatives that are of lower hazard. Operationalizing the NRC guidance for comparative exposure assessment, where information such as conditions of use, physicochemical properties and routes of exposure is considered in the assessment, can provide additional confidence in determining which alternative is safer, rather than relying solely on hazard assessment results (Whittaker 2018). Rating systems for the evaluation of qualitative exposure data could provide a relatively accessible approach to inclusion of comparative exposure information in alternatives assessments (Greggs et al. 2018; Kausch 2018). Nonetheless, case examples applying HESI’s qualitative exposure comparison approach highlighted that despite the utility of qualitative metrics for revealing differences in exposure characteristics between alternatives, the most important exposure trade-offs and their magnitude may be difficult to judge without quantitative exposure estimates (Greggs et al. 2018).

This article is protected by copyright. All rights reserved. 


\section{Developments in life-cycle considerations}

Speakers introduced advances in the use of life cycle impact considerations in alternatives assessment, including the utility of new data sources and new approaches. For example, the Environmental Genome Project provides a resource to construct an embedded supply chain chemical inventory for chemical manufacturing and products (Overcash 2016). A recent muti-phase project to identify a resin for additive manufacturing safer than those currently used in stereolithography provides an example of applying a life cycle-based approach to understanding the exposure potential for various stakeholders at different stages as well as a methodology for comparing impacts across all life cycle stages of the resin (Bours et al. 2017). Presenters noted the potential that life cycle-based methods, paired with high throughput exposure and toxicity approaches, can play in addressing data gaps in alternatives assessment (Fantke et al. 2018, Overcash et al. 2018).

\section{SHARED INSIGHTS FROM PRACTITIONERS}

Presentations throughout the Symposium demonstrated that alternatives assessments are being used and adapted to support decisions in many contexts—-from regulatory, to ecolabel criteria development and procurement activities to academic and research institute assessments (Argiles 2018, Davies 2018, Heine and Nestler 2019, Robertson 2018, Wigmore 2018, Zhou 2018). Despite these varied contexts, the general processes and frameworks used are consistent and include components identified as common to alternatives assessment (Jacobs et al. 2016). However, evolving alternatives assessment practice has identified several underappreciated aspects of the process.

This article is protected by copyright. All rights reserved. 


\section{Engaging stakeholders}

Multiple presenters discussed the importance of stakeholder engagement in alternatives assessments, beyond what the NRC (2014) report conveyed in the "scope and problem formulation” step. For example, a recent report notes the need to engage vulnerable communities to address equity concerns, reasoning that the groups most affected should be part of any trade-off decisions (NRDC 2017). Heine and Nestler (2019) note how engaging a diverse array of stakeholders was critical to the outcomes of a recent alternatives assessment on copper biocide anti-fouling paints for recreational boats, beyond simply providing access to data. At the urging of several stakeholder groups, Northwest Green Chemistry broadened the scope of the assessment beyond an evaluation of alternative biocidal coatings to include nonbiocidal coatings, as well as light, sound and mechanical anti-fouling technology alternatives. When the design and execution of the assessment was more inclusive of stakeholders, they were more vested and supportive of the final outcome. Canatsey (2018) discussed this benefit resulting from Sherwin William's effort to identify a safer alternative to bisphenol-A (BPA) in metal food can linings (Chemical Watch 2018b). The company engaged independent academic researchers who asked critical questions and conducted and published endocrine activity and migration tests, establishing deeper credibility in the safer hazard profile of the alternative (McGrath and Israel 2017).

\section{Thoughtfully considering tradeoffs}

A second consistently shared understanding among Symposium participants was that trade-offs should be systematically addressed as an inherent part of the alternatives assessment process. For example, based on experiences with the French

This article is protected by copyright. All rights reserved. 
Food, Environmental and Occupational Health and Safety (Anses) authority, Argiles (2018) noted the importance of clearly displaying the results of assessments to guide decision-makers. In an assessment of alternatives to formaldehyde used as a processing aid in the manufacture of animal feed, Anses' information tables displayed the advantages and disadvantages of the various alternatives against different criteria to help decision-makers identify the best option given organizational priorities. Recent efforts aim to develop more systematic, quantitative approaches to considering trade-offs, which can be used in the alternatives assessment process (Rao et al. 2018). For example, Dubrow and Risotto (2018) outlined the development of a more userfriendly multi-criteria decision analysis (MCDA) tool to assist companies and authorities with navigating tradeoffs in the analysis. However, researchers have found that formal decision support tools do not always lead to increased user satisfaction in a chosen alternative, suggesting the need for more guidance on how to use techniques such as MCDA (Malloy, Zaunbrecher, Batteate, et al. 2017) and structured decision making (Wilson and McDaniel 2007) in alternatives assessment processes (Beaudrie et al. 2018).

\section{Addressing the depth of analysis needed in different decision-contexts}

Symposium discussions identified a tension between the need for “straightforwardness," or simplicity, in the alternatives assessment approach given the resource and expertise constraints of many organizations completing assessments, versus comprehensiveness in the assessment that involves the use of more detailed quantitative methods. An increased engagement by academic scientific researchers in the field of alternatives assessment combined with some legal requirements, such as those under the California Safer Consumer Products (SCP) regulation (CA Code of 
Regulations 2013), are part of the driver for the latter. For example, a review of 13 publicly available alternatives assessments found that many have a narrower scope or are missing elements required in the SCP regulations (CA DTSC 2018).

Discussions highlighted the importance of investing in the "scope and problem formulation” step of an alternatives assessment, to assist with understanding where streamlining of specific elements of the assessment could take place and where additional depth and rigor in the assessment is important (NRC 2014). A tiered assessment approach was identified as one strategy for maximizing the benefits of both simplicity and expediency as well as increased rigor when needed to better address broader life cycle considerations. Nonetheless, because of the varying contexts in which alternatives assessment is being used, participants noted the importance of flexibility in the approach (see Geiser et al. 2015).

\section{RESEARCH AND PRACTICE NEEDS}

While the alternatives assessment community is beginning to fill important methodological gaps in alternatives assessment (see Tickner et al. this issue), participants highlighted a series of priority research and practice needs to support "building the field" — the theme of the 2018 Symposium. Importantly, participants identified a need to distinguish between alternatives assessment, the procedure of evaluating alternatives, and informed substitution, the process of adopting an alternative. There are research and practice needs related to both. Additionally, implementation is a critical last step of the alternatives assessment process, where additional trade-offs may be identified (NRC, 2014).

This article is protected by copyright. All rights reserved. 


\section{Developing guidance and standards of practice}

Discussions highlighted the need to develop guidance and standards of practice for the field of alternatives assessment. This can help improve consistency and quality as well as comparability between assessments. For example, based on an analysis of stakeholders' perceptions of knowledge gaps inhibiting alternatives assessment application and practice, Schoenung (this issue) highlighted the need for more detailed standards of practice guidance in particular for the types and sources of data used in hazard and exposure assessment processes as well as consideration of data quality and data-type prioritization.

\section{Increasing data and decision transparency}

Second, there was broad agreement on the important role of transparency in the alternatives assessment process, given that decision making occurs throughout the assessment process — not just in the final selection of alternatives (Heine and Nestler 2019, Malloy, Zaunbrecher, Batteate, et al. 2017, Zhou 2018). There is also a need for research and guidance on when and how to use different decision-making approaches, tools and methods to best fit the specific alternatives assessment context (Beaudrie et al. 2018). Malloy, Zaunbrecher, Batteate, et al. (2017) cautioned that decision tools cannot replace deliberation—people need to make decisions, not computers; decision tools are a support method and should not provide cover for strategic behavior.

\section{Building capacity}

Lastly, there was an emphasis on the need for capacity building and training to support both the alternatives assessment and substitution processes. Symposium participants made clear that new data sources, methods, and tools are becoming more available to better support alternatives assessment practice and informed substitution decisions. There was a broad call for trainings on a range of topics from basic This article is protected by copyright. All rights reserved. 
overviews of the alternatives assessment process to introduce professionals in diverse disciplines to the field, to more detailed content for experienced practitioners on various topics, such as best practices in the use of quantitative structure activity relationship (QSAR) resources and decision analysis tools (Spencer 2018). Additionally, participants noted the need for data sources and tools to allow practitioners with various levels of access to scientific resources to conduct quality, comprehensive assessments.

A number of capacity needs related to the design and adoption of safer alternatives were identified. For example, participants noted the value of the government programs that provide technical assistance to support the business community as they seek to evaluate and adopt safer and feasible alternatives. Alternatives assessment and substitution can be challenging, particularly for small companies with limited resources. Importantly, when no viable alternative exists, there is an opportunity to train companies to integrate alternatives assessment into product design, drive synergies in an end to end approach, and increase successful innovation of alternatives that meet desired performance, safety and circular economy targets. As such, there was clear recognition of the need to establish more comprehensive support programs for alternatives assessment and informed substitution efforts in academic and technical development trainings throughout the product development lifecycle-a pursuit that the newly launched A4 can help guide (see Box 1).

This article is protected by copyright. All rights reserved. 


\section{CONCLUSION}

As O’Brien (Grand Canyon Trust, personal communication) notes, it is the process of identifying and comparing alternatives against current practices that creates 'the magic' necessary to move towards chemicals, materials and technologies that are safer for humans and the environment. It is important to keep this goal in mind as the field of alternatives assessment grows. Alternatives assessment methods and practices have advanced to a great degree in the three years since the last convening of this growing community of practice. Despite this, Symposium discussions illustrated that significant science and practice gaps remain as well as capacity needs. Evolving practice has also identified a number of important cross-cutting aspects of alternatives assessment practice that will need to be elaborated in the future, in particular the mounting tension between "straightforwardness" and "comprehensiveness," which is common for any new field. The field has grown out of the need to evaluate and adopt safer chemicals, materials and products to replace those of concern. The speed and often level of detail required or desired in business decisions is frequently at odds with the slower, theoretical and knowledge-driven processes in academic research. Data gaps will likely continue to exist for various aspects of the assessment, as is common with other science-policy fields. Hence, in the case of alternatives assessment, rigor may not be defined only by the level of detail of or quantification of the assessment but also in terms of the comprehensiveness of and transparency in the process. A central question is whether the alternatives assessment process leads towards the goal of transitioning to safer, more sustainable chemicals, materials, and processes while avoiding regrettable substitutions.

This article is protected by copyright. All rights reserved. 
The Symposium made clear that governments, companies, and others are developing a range of alternatives assessment processes and tools to support the evaluation and adoption of safer chemicals, materials and products, with some more comprehensive (encompassing more steps of the NRC process) than others. As it grows, the field will need to establish "best practices" that build consistency in approaches yet remain sufficiently adaptable to different decision contexts. Being interdisciplinary by nature, continued growth of the field will require the engagement of multiple stakeholders-researchers and practitioners in industry and government, tapping their expertise across different disciplines, from hazard and exposure science, to lifecycle assessment, to economic and engineering assessment.

The establishment of the A4 represents the beginnings of formalization for the field of alternatives assessment. Over the coming years, the science and practice must evolve in a way that remains responsive to emerging market and policy drivers; is comprehensive yet efficient and effective; successfully links necessary theoretical and foundational research with pragmatic application and practice; engages a broad set of scientists and practitioners; and, stays true to the ultimate goal of supporting a transition to safer, more sustainable chemicals, materials, products, and processes.

\section{REFERENCES}

[A4] Association for the Advancement of Alternatives Assessment. 2018. 2018 Agenda. http://saferalternatives.org/2018-symposium/2018-agenda [accessed 2018 January 8].

Argiles G. 2018. Development of a methodological document for the comparison of alternatives to hazardous substances. 2018 International Symposium on Alternatives Assessment. November 1. https://saferalternatives.org/assets/documents/2ARGILES.pdf [accessed 2018 January 8].

Beaudrie C, Corbett C, Lewandowski T, Malloy T, Zhou X. Toward safer consumer products: Exploring the use of multi-criteria (MCDA) and structured decision making (SDM) approaches for chemical alternatives assessment. International Symposium on Alternatives Assessment. November 1.

This article is protected by copyright. All rights reserved. 
https://saferalternatives.org/assets/documents/2-Corbett.pdf [accessed 2018 January 8].

Bours J, Adzima B, Gladwin S, Cabral J, Mau S. 2017. Addressing hazardous implications of additive manufacturing: complementing life cycle assessment with a framework for evaluating direct human health and environmental impacts. Journal of Industrial Ecology, 21(S1), pp.S25-S36.

[CA] California Code of Regulations. (2013). Safer Consumer Products. Div 4.5, Tit 22, Chap 55. https://www.dtsc.ca.gov/LawsRegsPolicies/Regs/upload/Text-of-FinalSafer-Consumer-Products-Regulations-2.pdf. [accessed 2018 January 8].

[CA DTSC] California Department of Toxic Substances Control. 2017. Alternatives Analysis Guide, version 1.0. June.

https://www.dtsc.ca.gov/SCP/AlternativesAnalysisGuidance.cfm [accessed 2018 January 8].

[CA DTSC] California Department of Toxic Substances and Control. 2018. Alternatives Assessments: Examples and Lessons Learned. California Department of Environmental Protection. August.

https://www.dtsc.ca.gov/SCP/upload/AA_example_synopsis.pdf [accessed 2018 January 8].

Canatsey R. 2018. Alternatives development via safety by design: lessons and challenges.

International Symposium on Alternatives Assessment. November 1.

https://saferalternatives.org/assets/documents/S4.\%204\%20Canatsey.pdf [accessed 2018 January 8].

Chemical Watch. 2018a. Amazon to ban paint strippers containing methylene chloride and NMP. December 5. https://chemicalwatch.com/72525/amazon-to-ban-paintstrippers-containing-methylene-chloride-and-nmp. [accessed 2018 January 8].

Chemical Watch. 2018b. BPA could get canned. 28 November. https://chemicalwatch.com/72408/bpa-could-get-canned[accessed 2018 January 8].

[CPA] Clean Production Action. 2017. GreenScreen ${ }^{\circledR}$ for Safer Chemicals Hazard Assessment Guidance, Version 1.3 (2e). February.

Davies H. 2018. Certification of Safer Alternatives for PFAS-Free Firefighting Foams. 2018 International Symposium on Alternatives Assessment. November 1. https://saferalternatives.org/assets/documents/07-Davies.pdf [accessed 2018 January 8].

Dubrow S, Risotto S. 2018. A multi-criteria approach to alternatives assessment. 2018 International Symposium on Alternatives Assessment. November 1. https://saferalternatives.org/assets/documents/3-Dubrow.pdf [accessed 2018 January 8].

[EU] European Union. 2006. Regulation (EC) No. 1907/2006 of the European Parliament and of the Council of 18 December 2006 concerning the Registration,

This article is protected by copyright. All rights reserved. 
Evaluation, Authorisation and Restriction of Chemicals (REACH). https:/eurlex.europa.eu/legal-content/EN/TXT/?uri=CELEX\%3A02006R1907-20140410 [accessed 2018 January 8].

Fantke P, Jolliet O, Huang L. 2018. Toward a parsimonious life cycle based Alternatives Assessment (LCAA). 2018 International Symposium on Alternatives Assessment. November 1.

https://saferalternatives.org/assets/documents/05\%20Fantke.pdf [accessed 2018 January 8]

Fantke P, Illner N. 2018. Goods that are good enough: Introducing an absolute sustainability perspective for managing chemicals in consumer products. Current Opinion in Green and Sustainable Chemistry. 15:91-97

Geiser K, Tickner J, Edwards S, Rossi M. 2015. The architecture of chemical alternatives assessment. Risk Anal 35:2152-2161.

Greggs W, Burns T, Egeghy P, Embry MR, Fantke P, Gaborek B, Heine L, Jolliet O, Lee C, Muir D, Plotzke K, Rinkevich J, Sunger N, Tanir JY, Whittaker M. 2018. Qualitative approach to comparative exposure in alternatives assessment, Integr Environ Assess Manag. 2018 Jun 19. doi: 10.1002/ieam.4070.

Heine L, Nestler A. 2019. Promising Practices for Alternatives Assessment: Lessons from a Case Study of Copper-Free Antifouling Coatings. Integr Environ Assess Manag. Apr 30. doi: 10.1002/ieam.4165. [Epub ahead of print]

[IC2] Interstate Chemicals Clearinghouse. 2017. Alternatives Assessment Guide Version 1.1. January. http://theic2.org/article/downloadpdf/file_name/IC2_AA_Guide_Version_1.1.pdf [accessed 2018 January 8].

Jacobs M, Wang B, Rossi, MS. 2015. Alternatives to Methylene Chloride in Pain and Varnish Strippers. BizNGO/Clean Production Action. October 27.

https://www.cleanproduction.org/resources/entry/resource-methylene [accessed 2018 January 8].

Jacobs MM, Malloy TF, Tickner JA, Edwards S. 2016. Alternatives assessment frameworks: research needs for the informed substitution of hazardous chemicals. Environ Health Perspect 124:265-280.

Kausch M. 2018. C2C Certified's contextual material health methodology and its applicability to alternatives assessment. 2018 International Symposium on Alternatives Assessment. November 1. https://saferalternatives.org/assets/documents/03-Kausch.pdf [accessed 2018 January 8].

Kim ST, Chintagunta H, Schatz A. 2018. Integrated Checklist Approaches to Rapid Screening, Testing, and Assessment for Safer Alternative or Innovative Chemical Substances: Skin Sensitizers. 2018 International Symposium on Alternatives Assessment. November 1. https://saferalternatives.org/assets/documents/02-Kim.pdf [accessed 2018 January 8].

This article is protected by copyright. All rights reserved. 
Malloy TF, Zaunbrecher VM, Batteate CM, Blake A, Carroll WF, Corbett CJ, Hansen SF, Lempert RJ, Linkov I, McFadden R, Moran KD, Olivetti E, Ostrom NK, Romero M, Schoenung JM, Seager T, Sinsheimer P, Thayer KA. 2017. Advancing alternative analysis: Integration of decision science. Environ Health Persp. 125(6):066001-12.

Malloy TF, Zaunbrecher VM, Beryt E, Judson R, Tice R, Allard P, Blake A, Cote I, Godwin H, Heine L, Kerzic P, Kostal J, Marchant G, McPartland J, Moran K, Nel A, Ogunseitan O, Rossi M, Thayer K, Tickner J, Whittaker M, Zarker K. 2017.

Advancing alternatives analysis: the role of predictive toxicology in selecting safer chemical products and processes. Integr Environ Assess Manag. 13(5): 915-925.

McGrath T, Israel B. 2017. Valspar: How we engaged stakeholders to solve the BPA dilemma. https://www.greenbiz.com/article/valspar-how-we-engaged-stakeholderssolve-bpa-dilemma. [accessed 2018 January 8].

McKeag T, Bours J. 2018. Stereolithography Resins: Many Layers to a Safer SLA Resin. 2018 International Symposium on Alternatives Assessment. November 1. https://saferalternatives.org/assets/documents/07-McKeag.pdf [accessed 2018 January 8].

Morose G, Marshall J, McCarthy A, Harripersaud V, Giarosso A. 2017. Assessment of Safer and Effective Alternatives to Methylene Chloride for Paint Stripping Products. Lowell (MA): Toxics Use Reduction Institute. Report 2017-102

[NRC] National Research Council. 2014. A framework to guide selection of chemical alternatives. Washington DC: The National Academies Press.

[NRDC] Natural Resources Defense Council. 2017. Selecting Safer Alternatives to Toxic Chemicals and Ensuring the Protection of the Most Vulnerable: A Discussion Draft. https://www.nrdc.org/sites/default/files/toxicchemicals-vulnerable-populationsreport.pdf [accessed 2018 January 8].

O'Brien M. 2000. Making better environmental decisions: an alternative to risk assessment. Cambridge (MA): MIT Press.

Oregon Health Authority. 2018. Toxic Free Kids Act 2015. https://www.oregon.gov/oha/PH/HEALTHYENVIRONMENTS/HEALTHYNEIGH BORHOODS/TOXICSUBSTANCES/Pages/Toxic-Free-Kids.aspx [accessed 2018 January 8].

Overcash M, Fantke P, Jollet O, Griffing E. 2018. The Supply Chain Dimensions of Alterna6ves Assessment. 2018 International Symposium on Alternatives Assessment. November 1. https://saferalternatives.org/assets/documents/06-Overcash.pdf [accessed 2018 January 8].

Overcash M. 2016. Environmental genome of industrial products (EGIP): the missing link for human health. Green Chemistry. 18(12):3600-6.

Rao V, Francis R, Tanir J. 2018. Analyzing Chemical Substitution Decisions Among Chemical and Product Manufacturers. 2018 International Symposium on Alternatives

This article is protected by copyright. All rights reserved. 
Assessment. November 1. https://saferalternatives.org/assets/documents/1-Rao.pdf [accessed 2018 January 8].

Richevich J,Hackenmiller-Paradis R, Echols S, Gallegos L. Implementation of Quantitative Hazard Assessment Scoring Methods for High-throughput Chemical Alternatives Assessment. 2018 International Symposium on Alternatives Assessment. November 1. https://saferalternatives.org/assets/documents/6-Rinkevich.pdf [accessed 2018 January 8].

Robertson C. 2018. Customer driven material selection through transparency and market access requirements. 2018 International Symposium on Alternatives Assessment. November 1. https://saferalternatives.org/assets/documents/3Robertson.pdf [accessed 2018 January 8].

Schoenung J. Stakeholder Perception of Knowledge Gaps in the Alternatives Analysis Process toward Safer Consumer Products. Integrated Environmental Assess Management. [this issue]

Sciacca A. 2018. Home Depot, Lowe's to cease sales of chemical blamed in accidental deaths. Mercury News. June 20.

https://www.mercurynews.com/2018/06/20/home-depot-lowes-to-cease-sales-ofchemical-blamed-in-accidental-deaths/ [accessed 2018 January 8].

Smith M. 2018. Case Studies for Using In vitro and In silico Models to Prioritize Chemicals of Concern in Children's Products. [in publication]

Soto AM, Schaeberle C, Maier MS, Sonnenschein C, Maffini MV. 2017. Evidence of absence: Estrogenicity assessment of a new food-contact coating and the bisphenol used in its synthesis. Environ Sci Technol 51(3):1718-1726.

Spencer PJ. 2018. Best Practices for Addressing Human Health and Environmental Data Gaps in an Alternatives Assessment Context. 2018 International Symposium on Alternatives Assessment. November 1.

https://saferalternatives.org/assets/documents/03-Spencer.pdf [accessed 2018 January 8].

Szafran AT, Stossi F, Mancini MG, Walker CL, Mancini MA. 2017. Characterizing properties of non-estrogenic substituted bisphenol analogs using high throughput microscopy and image analysis. PLoS One. 12(7):e0180141. doi:

10.1371/journal.pone.0180141

Tickner J. 2018. Evolution of the Field: An Historical Perspective. 2018 International Symposium on Alternatives Assessment. November 1. http://saferalternatives.org/assets/documents/S1.\%201.\%20Tickner.pdf [accessed 2018 January 8].

Tickner J, Jacobs M, Malloy T, Buck T, Stone A, Blake A, Edwards, S. 2018. Advancing alternatives assessment for safer chemical substitution: a research and practice agenda. Integr Environl Assess Management. 018 Aug 17. doi:

10.1002/ieam.4094.

This article is protected by copyright. All rights reserved. 
U.S. Council on Environmental Quality. 2005. Regulations for Implementing the Procedural Provisions of the National Environmental Policy Act, 4 CFR 1500-1508, Reprint, Available at: http://energy.gov/sites/prod/files/NEPA-40CFR1500_1508.pdf accessed December 31, 2018.

[U.S. EPA] US Environmental Protection Agency. 2009. EPA’s Safer Choice Standard (formerly, the 'DfE Standard for Safer Products'). Washington (DC): US Environmental Protection Agency. [cited 2018 January 8].

https://www.epa.gov/sites/production/files/2013-12/documents/standard-for-saferproducts.pdf

[U.S. EPA] U.S. Environmental Protection Agency. 2011. Alternatives Assessment Criteria for Hazard Evaluation. Version 2.0. August 2011. U.S. EPA, Office of Pollution Prevention \& Toxics. 2011 Available: http://www2.epa.gov/sites/production/files/2014-01/documents/aa_criteria_v2.pdf [accessed December 31, 2018].

[Wash RCW] Revised Code of Washington. 2018. Prohibition of the Manufacture, Sale or Distribution of Certain Food Packaging. Chap 70.95G.070. https://app.leg.wa.gov/RCW/default.aspx?cite=70.95G.070 [accessed 2018 January 8].

Whittaker M. 2018.The State of the Science of Alternatives Assessment Methods: Comparative Exposure Characterization. 2018 International Symposium on Alternatives Assessment. November 1. https://saferalternatives.org/assets/documents/S2.\%202.\%20Whittaker.pdf [accessed 2018 January 8].

Wigmore D. 2018. Tools for informed substitution: Integrating health and safety committee and procurement activities. 2018 International Symposium on Alternatives Assessment. November 1. https://saferalternatives.org/assets/documents/7Wigmore.pdf [accessed 2018 January 8].

Wilson C, McDaniels T. 2007. Structured Decision-Making to Link Climate Change and Sustainable Development. Risk Analysis. 7: 353-370

Zhou, X. 2018. Lessons Learned from Alternatives Assessment Examples Review for California’s Safer Consumer Products Alternatives Analysis. 2018 International Symposium on Alternatives Assessment. November 1. http://saferalternatives.org/assets/documents/S4.\%202\%20Zhou.pdf [accessed 2018 January 8].

This article is protected by copyright. All rights reserved. 


\section{FIGURE}

Figure 1: The Evolution of Alternatives Assessment and Informed Substitution

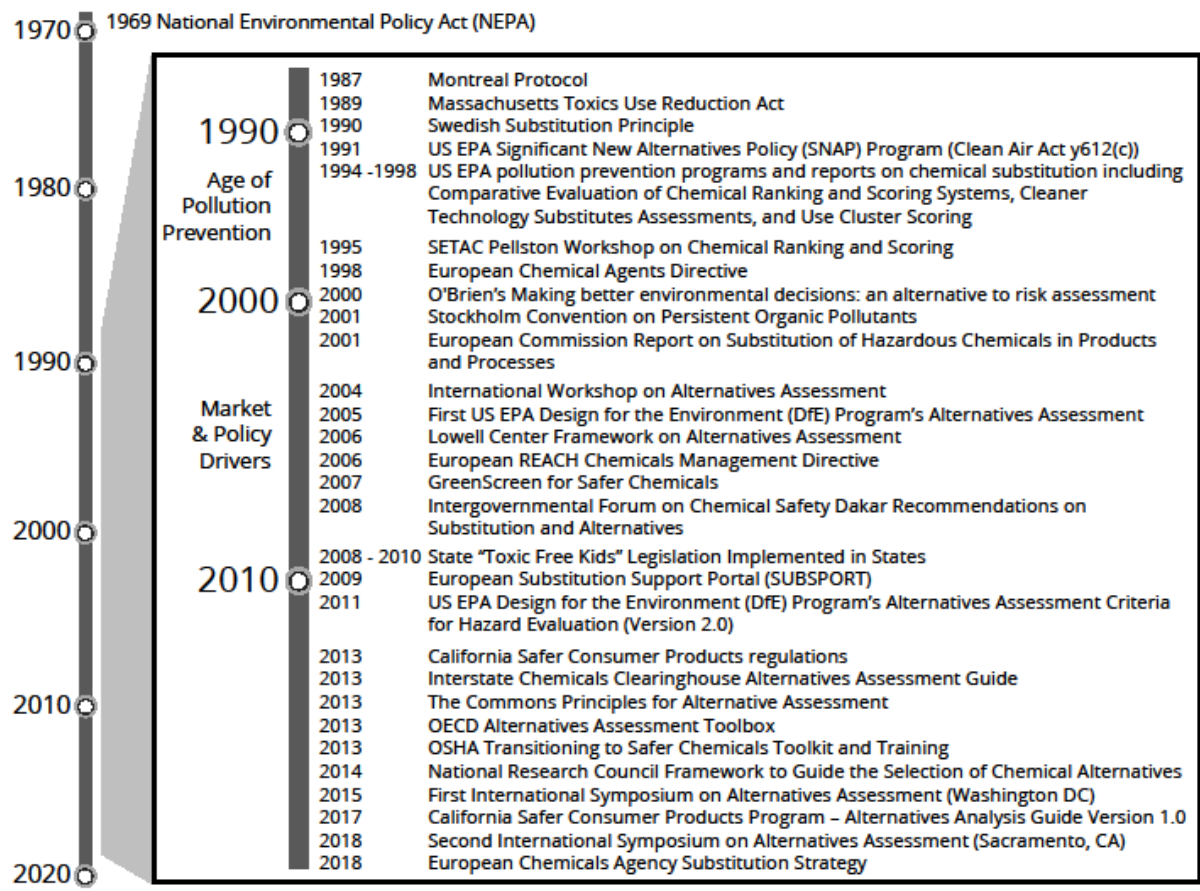

Box 1: Association for the Advancement of Alternatives Assessment (A4)

\section{Box 1: Association for the Advancement of Alternatives Assessment (A4)}

The Symposium also marked the launch of A4, a new professional society dedicated to the science and practice of alternatives assessment and informed substitution. The mission of A4 is to enhance the science of alternatives assessment, advance informed substitution, and support a vibrant, effective community of practitioners. The vision of A4 is that every essential function performed by a chemical, material, process, or product is achieved with safe and sustainable solutions. One aspiration in building a formalized community of practice is to infuse safer alternatives thinking or a substitution mindset in government, industrial and academic chemicals assessment, development and management research, training, and practice. Initially, A4 will work on consistency and best practices in elements of alternatives assessment, education and training, and networking of experts.

This article is protected by copyright. All rights reserved. 


\begin{tabular}{|c|l|}
\hline \multicolumn{2}{|c|}{ Table 1: Elements of Alternatives Assessment } \\
\hline \multirow{2}{*}{ BOUNDS OF ANALYSIS } & Scoping, problem formulation \\
\cline { 2 - 3 } & Identify alternatives \\
\hline \multirow{2}{*}{ EVALUATION } & Hazard assessment \\
\cline { 2 - 3 } & Exposure characterization \\
\cline { 2 - 3 } & Other life cycle considerations \\
\hline \multirow{2}{*}{ IMPLEMENTATION } & Link to Safer Chemistry and/or Technology Research \\
\cline { 2 - 3 } & and Development \\
\hline \multirow{2}{*}{ FEASIBILITY } & Technical feasibility assessment \\
\cline { 2 - 3 } & Comparative economic feasibility assessment \\
\hline & Decision making \\
\hline & Adoption \\
\hline
\end{tabular}

This article is protected by copyright. All rights reserved. 